\section{Scientific journal}

PHYSICAL AND MATHEMATICAL EDUCATION

Has been issued since 2013.

Науковий журнал

ФІЗИКО-МАТЕМАТИЧНА ОСВІТА

Видається $з 2013$.
ISSN 2413-158X (online)

ISSN 2413-1571 (print)

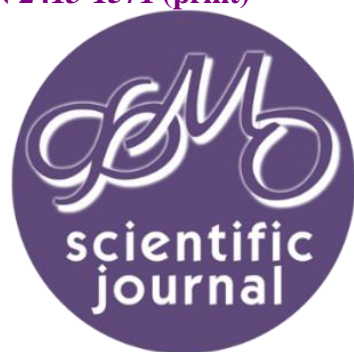

Сачанюк-Кавецька Н.В., Кавецький В.В. Застосування критерію Фішера для забезпечення достовірності результатів оцінювання залишкових знань студентів. Фізико-математична освіта. 2021. Випуск 2(28). С. 71-76.

Sachaniuk-Kavets'ka N., Kavetskiy V. Application of Fisher's criterion to ensure the results of the students residual evaluation. Physical and Mathematical Education. 2021. Issue 2(28). P. 71-76.

DOI 10.31110/2413-1571-2021-028-2-012

УдК 519.21(075.8)

Н.В. Сачанюк-Кавецька Вінницький національний технічний університет, Україна skn1901@gmail.com

ORCID: 0000-0001-6405-133

В.В. Кавецький

Вінницький національний технічний університет, Україно kvslavoff@gmail.com

ORCID: 0000-0001-8752-0807

\title{
ЗАСТОСУВАННЯ КРИТЕРІЮ ФІШЕРА ДЛЯ ЗАБЕЗПЕЧЕННЯ ДОСТОВІРНОСТІ РЕЗУЛЬТАТІВ ОЦІНЮВАННЯ ЗАЛИШКОВИХ ЗНАНЬ СТУДЕНТІВ
}

\section{АНОТАЦІЯ}

Формулювання проблеми. В сучасних педагогічних дослідженнях особливе місце посідають залишкові знання з навчальних дисциплін, які фіксуються в пам'яті студентів через достатньо великі проміжки часу, але роль яких є визначальною у становленні їх як фрахівців. Проблема достовірності результатів оцінювання залишкових знань студентів $\epsilon$ актуальною, оскільки ці результати є вихідною інформацією для оптимізації та модернізації освітнього процесу. 3 огляду на зазначене постає необхідність з'ясувати можливість порівняння успішності студентів різних років, що навчались в однакових умовах за залишковими знаннями, обрати критерій такого порівняння та з'ясувати, чи $\epsilon$ чі знання сталою величиною.

Матеріали і методи. Для виконання завдань дослідження використано методи: аналіз, синтез, порівняння, систематизація та узагальнення навчально-методичних та науково-популярних джерел з проблеми дослідження, педагогічний експеримент, первинна статистична обробка й узагальнення отриманих даних. Дослідження проведено на баз Вінницького національного технічного університету при кафедрі вищої математики. Обсяг вибірки - 40.

Результати. При аналізі залишкових знань на базі комплексних контрольних робіт (ККР) з метою подальшого коригування форм, методів і засобів навчання застосовано спеціальні методики їх обробки, розглянуто можливість застосування критерію Фішера (кутового перетворення Фішера) для оцінювання наявності (відсутності) дійсної розбіжності в рівнях підготовки студентських груп, які навчались в однакових умовах.

Висновки. Для забезпечення прийняття достовірного рішення доцільно застосовувати критерій Фішера, що дозволить оиінити дійсну розбіжність в рівнях підготовки студентських груп, які навчались в однакових умовах, однак різняться кількістю студентів в групі. Аналізуючи статистичні коефіцієнти можна стверджувати, що рівень та якість залишкових знань залишається сталою величиною, не залежно від того, вчили студенти цей матеріал в минулому семестрі, чи в минулому році. Для більш чіткого визначення рівня цих знань потрібно використовувати ширшу оціночну шкалу, а не традиційну п'ятибальну.

КлючОвІ СЛОвА: оцінювання залишкових знань; критерій Фішера; оцінювання розбіжності в підготовці студентських груп; достовірність порівнянь.

ВСТУП

Постановка проблеми. Контроль знань студентів представляє собою безперервний процес, який розпочинається з моменту зарахування студента до закладу вищої освіти (ЗВО) та завершується заходами державної атестації. Рівень оволодіння ключовими компетенціями на вході оцінюється за допомогою вхідного педагогічного контролю як елемента педагогічної діагностики. Рівень знань студентів в процесі навчання оцінюється за допомогою поточного контролю знань. Рівень оволодіння ключовими компетенціями на виході забезпечується за допомогою підсумкового педагогічного контролю. Моніторинг знань студентів протікає як процес, основною метою якого є отримання вихідної інформації для 
вдосконалення навчальних заходів. Важливим показником якості підготовки у закладі вищої освіти також $\epsilon$ міцність засвоєння навчального матеріалу студентами. Виходячи з цього однією зі складових технології оцінювання якості освіти $€$ перевірка залишкових знань.

Під залишковими знаннями розуміють «певний обсяг інформації, співвіднесений з освітніми стандартами, навчальними планами і програмами, який зберігається в довготривалій пам'яті студента на фіксований момент часу і під впливом відповідних стимулів може бути використаний ним під час навчальної та професійної діяльності» (Кислякова, 2002). Контроль залишкових знань студентів $€$ (поряд з поточним, рубіжним і заключним контролем) однією 3 організаційних форм перевірки засвоєння навчального матеріалу. Однак, оцінювання залишкових знань студентів $€$ однією з невирішених проблем в освіті. Це оцінювання необхідне для педагогічного діагностування, корекції освітнього процесу, вибору форм та методів викладання дисциплін, оцінювання якості освіти, ефективного управління освітою. Значною мірою процедура перевірки залишкових знань використовується у сфері вищої освіти, оскільки дана система має значно більше можливостей для внесення змін в освітній процес як на індивідуальному рівні, так і на рівні закладу освіти. Результати контроля залишкових знань студентів $є$ одним з факторів, які мають значення при ліцензуванні закладу вищої освіти та акредитації навчальних програм. Контроль залишкових знань повинен мати ознаки цілеспрямованості, об'єктивності, повноти, адекватності, а також інформативності та наочності представлення результатів. Остання ознака необхідна для того, щоб за результатами проведеної перевірки можна було зробити правильні висновки і за потреби організувати коригувальний процес.

У відповідності до «Положення про методику управління та контролю якості навчання у Вінницькому національному технічному університеті» (Леонтьєв\&Лисенко\&Котлярова, 2007) щороку проводяться ректорські комплексні контрольні роботи з дисциплін, які вивчалися в попередньому навчальному семестрі. Контрольне завдання ККР - це перелік формалізованих запитань (тестів) чи завдань, вирішення яких потребує уміння застосовувати інтегровані знання програмного матеріалу дисципліни, до того ж, ККР повинна мати однакову структуру (за кількістю запитань або тестів), бути рівнозначної складності, а трудомісткість відповідати відведеному часу контролю. Фактично, залишкові знання з навчальних дисциплін $є$ кінцевою метою діяльності будь-якої навчальної системи, в якій формування знань відбувається в результаті інформаційної взаємодії ї̈ структурно взаємопов'язаних і функціонально взаємозалежних компонентів: студентського, соціального, викладацького середовищ та підсистеми моніторингу знань, кожна з яких може розглядатись як самостійна складна система. Контроль у дидактиці вищої школи слід розуміти як педагогічний супровід, спостереження і перевірку успішності навчально-пізнавальної діяльності.

Контролюючи навчально-пізнавальну діяльність студентів, викладач спрямовує свої зусилля на вирішення таких завдань:

- виявлення якості засвоєння навчального матеріалу, ступеня відповідності отриманих умінь і навичок цілям і завданням навчальної дисципліни;

- виявлення складнощів у засвоєнні студентами навчальної інформації та типових помилок з метою їх корекції та усунення;

- визначення ефективності організаційних форм, методів і засобів навчання;

- діагностування рівня готовності студентів до сприйняття нового матеріалу.

Результати ККР обговорюють на засіданні кафедри та методичних комісій напрямів, причому:

- розглядають результати виконання завдань ККР за зведеними відомостями за напрямами та спеціальностями;

- порівнюють результати виконання завдань ККР з оцінками семестрового контролю;

- розглядають ухвалені кафедрами рекомендації щодо удосконалення викладання відповідних навчальних дисциплін;

- обговорюють та приймають ухвали щодо вжиття заходів для усунення та недопущення виникнення невідповідності у підготовці фахівців.

Проводячи аналіз результатів ККР часто доводиться проводити статистичний та порівняльний аналіз даних з метою подальшого коригування форм, методів і засобів навчання. Разом з тим, за наявності великої кількості публікацій за даною тематикою (Артищева, 2015; Чмыхова\&Терехин, 2010; Крицкая\&Белов, 2015), актуальними залишаються проблеми обробки, аналізу та інтерпретації отриманих даних.

Досить часто дослідники без перевірки ступеня співпадіння отриманого емпіричного розподілу з нормальним, використовують дисперсійний аналіз - аналіз варіативності ознаки під дією довільних контрольованих змінних факторів. При цьому припускається, що одні змінні можуть розглядатись як причини, а інші - як наслідки. Однак специфіка педагогічних та психологічних даних така, що виділення факторів та результативних ознак залежить від мети дослідження, шкали для оцінки змін досліджуваних параметрів, тощо. Нехай, наприклад, ми припускаємо, що наполегливість - суттєвий фактор навчальної успішності студентів і цю психологічну ознаку приймаємо за фактор, а навчальну успішність - за результативну ознаку. Контраргументів щодо такого припущення $\epsilon$ два. По-перше, успіх може стимулювати наполегливість. По-друге, як власне виміряти наполегливість? Якщо вона вимірювалась за допомогою експертних оцінок, а експертами були одногрупники та викладачі, то не виключено, що ця оцінка наполегливості буде залежати від відомих експертам показників успішності, а не навпаки. Тільки дослідницька інтуїція може підказати, що є причиною, а що результатом. Однак не завжди ці відчуття у різних дослідників співпадають, тому використання нормального закону розподілу при дослідженні психолого-педагогічних ознак призведе до помилок та хибних висновків.

Мета статті. 3 огляду на зазначене вище, метою статті $€$ висвітлення питання забезпечення достовірності результатів оцінювання залишкових знань; опис педагогічного експерименту з виявлення відмінностей успішності студентів різних років навчання з дисципліни «Вища математика»; обґрунтування застосування непараметричних методів для роботи із специфічними психолого-педагогічними даними. 


\section{МЕТОДИ ДОСЛІДЖЕННЯ}

Для виконання завдань дослідження використано методи: аналіз, синтез, порівняння, систематизація та узагальнення навчально-методичних та науково-популярних джерел 3 проблеми дослідження, педагогічний експеримент, первинна статистична обробка й узагальнення отриманих даних. Дослідження проведено на базі Вінницького національного технічного університету при кафедрі вищої математики.

\section{РЕЗУЛЬТАТИ ДОСЛІДЖЕННЯ ТА ОБГОВОРЕННЯ}

Статистичний критерій - це вирішальне правило, що забезпечує прийняття істинної та відхилення хибної гіпотези з високою ймовірністю. Існують параметричні та непараметричні критерії. Параметричні критерії включають в формулу розрахунку параметри розподілу, тобто середні та дисперсії ( $t$-критерій Ст'юдента, критерій $F$ і ін.). Непараметричні критерії не включають в формулу розрахунку параметри розподілу і базуються на оперуванні частотами або рангами (критерії $U, Q, \varphi^{*}$ і ін.). Зрозуміло, що параметричні критерії більш потужні, оскільки дозволяють точно оцінити відмінності в середніх, отримані в двох вибірках ( $t$-критерій Ст'юдента) та відмінності в дисперсіях (критерій Фішера). Вони дають змогу виявити тенденції зміни ознаки при переході від умови до умови (дисперсійний аналіз), але тільки в тому випадку, якщо ознаку виміряно за інтервальною шкалою та нормально розподілено (те що ознака має нормальний розподіл вимагає математико-статистичної перевірки). Слід відмітити, що дані, подані не в стандартизованих оцінках можна вважати інтервальними $з$ досить малою ймовірністю. Більше того, для параметричних критеріїв характерні складні математичні обрахунки. Експериментальні дані для непараметричних критеріїв можуть не відповідати жодній з таких умов: значення ознаки представлені за будь-якою шкалою; розподіл ознаки може бути довільним і співпадіння його з будь-яким теоретичним законом не є обов'язковим та не потребує перевірки; вимоги рівності дисперсій відсутні. Математичні обрахунки не потребують тривалого часу та не надто складні. Непараметричні критерії дозволяють оцінити середні тенденції, відмінності в діапазонах варіативності ознаки та тенденції зміни ознаки при переході від умови до умови за будь-якого розподілу ознаки. У порівнянні з параметричними критеріями дані критерії обмежені лише в одному - з їх допомогою неможливо оцінити взаємодію двох або більше умов чи факторів, що впливають на зміну ознаки. Цю задачу можна розв'язати лише за допомогою двофакторного дисперсійного аналізу.

Враховуючи можливості та обмеження параметричних та непараметричних критеріїв, для обробки, аналізу та інтерпретації отриманих психолого-педагогічних даних доцільно використовувати непараметричні критерії. При аналізі результатів ККР з метою подальшого коригування форм, методів і засобів навчання необхідно врахувати наступні фактори:

1) Індивідуальний підхід до оцінки навчальних успіхів студентів в підсумковому контролі, що передбачає виявлення рівня знань, умінь та навичок кожного студента, шляхом вибору методів контролю з урахуванням індивідуальних особливостей особистості (типу темпераменту, здібностей, особливостей реакції на стресову ситуацію тощо).

2) Здійснення постійного цілеспрямованого контролю протягом усього періоду навчання у закладі вищої освіти 3 використанням поточних результатів.

3) Максимально точне визначення рівня навчальних досягнень студентів на основі єдиних вимог згідно критеріїв, окреслених навчальними програмами.

4) Контроль рівня засвоєння знань повинен включати перевірку і оцінювання теоретичних знань та здатність студентів до їх застосування на практиці.

5) Професійна спрямованість контролю зумовлюється цільовою підготовкою спеціалістів у закладі вищої освіти та має сприяти підвищенню мотивації до навчально-пізнавальної діяльності майбутніх фахівців.

Дані фактори дають підґрунтя для формування ідеальних умов щодо застосування багатофункціональних статистичних непараметричних критеріїв для порівняння успішності студентів за результатами проведення ККР. Багатофункціональні статистичні критерії можуть бути застосовані до різноманітних даних, вибірок та задач (Плохинский, 2015; Гублер, 1978). Ці критерії побудовані на співставленні часток, що виражені в частках одиниці чи відсотках, тому з'являється можливість проведення порівняльного аналізу успішності студентів різних років навчання. Зміст критеріїв полягає у визначенні того, яка частка спостережень у даній вибірці характеризується ефектом, що нас цікавить, і яка частка цим ефектом не характеризується.

Таким ефектом може бути:

1) конкретне значення ознаки, що визначається якісно - наприклад, згода з якимось висновком; віднесеність до певної категорії студентів за успішністю («відмінник», «ледар») тощо;

2) певний рівень ознаки, що вимірюється кількісно - наприклад, отримання оцінки, що перевищує середній бал успішності групи за екзаменаційними відомостями; кількість правильних відповідей на тестові запитання кожним студентом групи тощо.

Таким чином, шляхом зведення довільних даних до альтернативної шкали «€ ефект - немає ефекту» багатофункціональні критерії дозволяють розв'язувати всі наведені задачі співставлення - порівняння категорій студентів та рівня засвоєння знань. Необхідно також пам'ятати, що будь-яке вимірювання повинно давати об'єктивний, надійний і достовірний результат. Особливо важливо це для вимірювання, заснованого на опосередкованій інформації, в тому числі для педагогічного оцінювання. Для повноцінної діагностики результатів засвоєння навчального предмета необхідно оцінювати не тільки індивідуальні знання кожного учня, але і фоновий рівень знань, причому не тільки однієї визначеної групи, але і інших груп певного курсу які вивчали дану дисципліну. При діагностиці фонового рівня знань студентської групи, як цілісної одиниці забезпечується всебічне охоплення змісту певного навчального предмета, що перевіряється; з'являється можливість багатоваріантного контролю результатів засвоєння навчального предмета; спрощується контроль над процедурою проведення діагностичної роботи тощо. Однак при проведенні аналізу успішності групи можуть виникнути психологічні проблеми сприйняття отриманих даних, коли різниця в отриманих відсотках якості та успішності 
різних груп з різною кількістю студентів, візуально вказують на суттєві відмінності в рівні залишкових знань. Хоча це може бути не зовсім об'єктивно. Тому для забезпечення прийняття достовірного рішення необхідно підібрати певний критерій, який дозволить оцінити дійсну розбіжність в рівнях підготовки студентських груп, які навчались в однакових умовах, однак різняться кількістю студентів в групі, що забезпечує зведення даних груп як ідентичних при проведенні достовірного порівняння.

До числа багатофункціональних критеріїв, які відповідають вимогам до аналізу успішності знань студентів при проведенні ККР, повною мірою відноситься критерій $\varphi^{*}$ Фішера (кутове перетворення Фішера). Кутове перетворення Фішера застосовують в тих випадках, коли обстежено дві вибірки досліджуваних і призначений він для співставлення цих вибірок за частотою появи ефекту, який цікавить дослідника. В даному випадку це успішність студентів за залишковими знаннями.

Для аналізу успішності та формування висновків про рівень залишкових знань студентів різних курсів навчання (2-й та 3-й) при вивченні та завершенні вивчення курсу «Вища математика» застосуємо перетворення Фішера до двох досліджуваних груп ФЕЕЕМ ВНТУ (Сачанюк-Кавецька, 2018) з врахуванням обов'язкових для цього критерію обмежень. Гіпотетично, рівень залишкових знань має бути вищим у студентів 3-го курсу, які повністю завершили вивчення дисципліни, тому розглянемо їх результати ККР (група кількістю $n_{1}=19$ осіб). В якості контрольної групи порівняння візьмемо групу 2-го курсу (кількістю $n_{2}=21$ особа). В даному варіанті використання критерію ми порівнюємо відсоток досліджуваних, що характеризуються наявністю оцінок «добре» та «відмінно» в одній вибірці, з відсотком досліджуваних в іншій вибірці, що характеризуються тією ж якістю. Такі оцінки як «добре» та «відмінно» з ККР отримали відповідно 11 та 10 студентів з першої та другої групи, взятих для аналізу. В першому випадку відсоткова частка тих, що розв'язали задачу становить $\frac{11}{19} \cdot 100 \%=58 \%$, а в другому $\frac{10}{21} \cdot 100 \%=48 \%$.

Чи достовірно, що при даних $n_{1}$ та $n_{2}$ ці відсоткові частки відмінні? Здавалося 6, що 58\% суттєво перевищує $48 \%$. Перевіримо отриману відмінність. Оскільки нас цікавить факт отримання оцінок «добре» та «відмінно» з КкР, будемо вважати «ефектом» наявність таких оцінок, а відсутність ефекту - отримані оцінки «незадовільно» та «задовільно».

Сформулюємо гіпотези для наближення нашої практичної задачі до застосування перетворення Фішера.

$H_{0}$ : Частка осіб, що отримали оцінки «добре» та «відмінно» з ККР в першій групі не більша, ніж в другій.

$H_{1}$ : Частка осіб, що отримали оцінки "добре» та «відмінно» з ККР в першій групі більша, ніж в другій.

Побудуємо таблицю, яка фактично $є$ таблицею емпіричних частот за двома значеннями ознаки: «є ефект» - «немає ефекту» (табл. 1).

Таблиця 1

Таблиця емпіричних частот досліджуваної ознаки

\begin{tabular}{|c|c|c|c|c|c|c|c|}
\hline \multirow{2}{*}{$\begin{array}{l}\text { ㄴ } \\
\text { 은 }\end{array}$} & \multicolumn{3}{|c|}{ «€ ефект»: одержано якісну оцінку з ККР } & \multicolumn{3}{|c|}{$\begin{array}{c}\text { «Немає ефекту»: одержано «задовільно» або } \\
\text { «незадовільно» з ККР }\end{array}$} & \multirow{2}{*}{$\sum_{j}^{s}$} \\
\hline & Кількість студентів & Відсоткова частка & & Кількість студентів & Відсоткова частка & & \\
\hline 3-й курс & 11 & $58 \%$ & A & 8 & $42 \%$ & 5 & 19 \\
\hline 2-й курс & 10 & $48 \%$ & $\mathrm{~B}$ & 11 & $52 \%$ & $\Gamma$ & 21 \\
\hline Суми & 21 & & & 23 & & & 40 \\
\hline
\end{tabular}

За статистичною таблицею величини кута $\varphi$ для різних відсоткових часток (Урбах, 1975), визначимо величини $\varphi$, які відповідають кожній з груп.

В нашому випадку $\varphi_{1(58 \%)}=1,731, \varphi_{2(48 \%)}=1,531$. Тепер обчислимо емпіричне значення $\varphi^{*}$ за формулою:

$$
\varphi^{*}=\left(\varphi_{1}-\varphi_{2}\right) \cdot \sqrt{\frac{n_{1} \cdot n_{2}}{n_{1}+n_{2}}},
$$

де $\varphi_{1}$ - кут, що відповідає більшій відсотковій частці; $\varphi_{2}-$ кут, що відповідає меншій відсотковій частці; $n_{1}-$ кількість спостережень у вибірці $1 ; n_{2}$ - кількість спостережень у вибірці 2.

В даному випадку: $\varphi_{e m p}^{*}=(1,731-1,531) \cdot \sqrt{\frac{19 \cdot 21}{19+21}}=0,2 \cdot \sqrt{9,975}=0,63$.

Для рівня значимості $\rho=0,05$ знайдемо критичне значення критерію: $\varphi_{k r y t}^{*}=1,64$.

Оскільки $\varphi_{\text {emp }}^{*}<\varphi_{k y y t}^{*}$, то гіпотеза $H_{0}$ приймається. Частка студентів, що отримали оцінки «добре» та «відмінно» 3 ККР, в першій групі не більша, ніж в другій групі. За проведеним дослідженням згідно перетворенню Фішера, ці відмінності за даної кількості студентів в групах не достовірні. Тому, те що здавалось суттєвим, із статистичної точки зору може таким не виявитись. За якісного підбору комплекту завдань в ККР, який має відповідати зрізу знань, кількість років навчання істотним чином не впливає на успішність студентів при засвоєнні нової інформації.

Відмітимо, що для узагальнення результатів перевірки критерій Фішера можна застосувати для співставлення вибірок за ознакою, що вимірюється кількісно. В даному варіанті використання критерію ми порівнюємо відсоток студентів в одній вибірці, які досягають певного рівня значення ознаки, з відсотком студентів, які досягли цього рівня в другій вибірці. Стандартна ККР з «Вищої математики» містить шість задач. Відправною ознакою будемо вважати кількість задач розв'язаних з детальним обґрунтуванням. Під явищем «Є ефект» будемо вважати більше ніж чотири задачі розв'язані з обґрунтуванням, «Немає ефекту» - менше чотирьох задач розв'язаних з обґрунтуванням. (Чотири задачі 
становлять $2 / 3$ загальної кількості завдань ККР). Дану ознаку розглядаємо в роботах студентів, які отримали оцінки "добре» або «задовільно»: в першій контрольній групі це чотири з одинадцяти студентів, а в другій - шість з десяти. Одержані показники наведено в табл. 2

Показники кількості розв'язаних задач з обгрунтуванням

\begin{tabular}{|l|l|l|l|l|}
\hline \multirow{2}{*}{\multicolumn{1}{|c|}{ явище }} & \multicolumn{2}{c|}{ Група 1 (3-й курс) } & \multicolumn{2}{c|}{ Група 2 (2-й курс) } \\
\cline { 2 - 5 } & Кількість обґрунтованих розв'язків & \% частка & Кількість обґрунтованих розв'язків & \% частка \\
\hline «Єефект» & $4 ; 4 ; 5 ; 6$ & $36,4 \%$ & $4 ; 4 ; 5 ; 5 ; 6 ; 6$ & $60 \%$ \\
\hline «емає ефекту» & $3 ; 3 ; 3 ; 3 ; 2 ; 2 ; 2$ & $63,6 \%$ & $3 ; 3 ; 3 ; 3$ & $40 \%$ \\
\hline Суми & 39 & $100 \%$ & 42 & $100 \%$ \\
\hline Середні & 3,5 & 4,2 & \\
\hline
\end{tabular}

Формуємо гіпотези: $H_{0}$ : Частка студентів, котрі оформили розв'язки більше чотирьох задач в групі третього курсу не більша ніж в групі студентів другого курсу. $H_{1}$ : Частка студентів, котрі оформили розв'язки більше чотирьох задач в групі студентів третього курсу більша ніж в групі студентів другого курсу.

Тепер побудуємо так звану чотириклітинну таблицю (табл. 3).

Таблиця 3

Чотириклітинна таблиця розрахунку критерію $\varphi^{*}$

\begin{tabular}{|l|l|l|l|l|l|}
\hline \multirow{2}{*}{ Групи } & \multicolumn{2}{|l|}{ « ефект» } & «Немає ефекту» & $\sum$ \\
\cline { 2 - 5 } & Кількість студентів & \% частка & Кількість студентів & \% частка & \\
\hline $3-\breve{~ к у р с ~}$ & 4 & $36,4 \%$ & 7 & $63,6 \%$ & 11 \\
\hline $2-\breve{~ к у р с ~}$ & 6 & $60 \%$ & 4 & $40 \%$ & 10 \\
\hline$\sum$ & 10 & & 11 & & 21 \\
\hline
\end{tabular}

За статистичними таблицями: $\varphi_{36,4 \%}^{*}=1,295, \varphi_{60 \%}^{*}=1,772$. Розрахуємо емпіричне значення нашого критерію: $\varphi_{\text {emp }}^{*}=(1,772-1,295) \cdot \sqrt{\frac{10 \cdot 11}{10+11}}=0,477 \cdot 2,289 \approx 1,092 . \quad$ В нашому випадку $\quad \varphi_{\text {emp }}^{*}<\varphi_{k r y t}^{*}=\left\{\begin{array}{ll}1,64 & (\rho \leq 0,05) \\ 2,31 & (\rho \leq 0,01)^{\prime}\end{array}\right.$ тому приймається гіпотеза $H_{0}$ : частка студентів, котрі оформили розв'язки більше чотирьох задач в групі третього курсу не більша ніж в групі студентів другого курсу.

\section{ВИСНОВКИ ТА ПЕРСПЕКТИВИ ПОДАЛЬШОГО ДОСЛІДЖЕННЯ}

Контроль знань студентів представляє собою безперервний процес, який розпочинається з моменту зарахування студента до ЗВО та завершується заходами державної атестації. Важливим показником якості підготовки у закладі вищої освіти є міцність засвоєння навчального матеріалу студентами. Виходячи з цього однією зі складових технології оцінювання якості освіти $€$ перевірка залишкових знань. Моніторинг знань студентів протікає як процес, основною метою якого є отримання вихідної інформації для вдосконалення навчальних заходів.

Будь-яке вимірювання повинно давати об'єктивний, надійний і достовірний результат. Особливо важливо це для вимірювання, заснованого на опосередкованій інформації, в тому числі для педагогічного оцінювання. При проведенні аналізу успішності групи можуть виникнути психологічні проблеми сприйняття отриманих даних, коли різниця в отриманих відсотках якості та успішності різних, груп з різною кількістю студентів, візуально вказують на суттєві відмінності в рівні залишкових знань. Для забезпечення прийняття достовірного рішення доцільно застосовувати критерій Фішера, що дозволить оцінити дійсну розбіжність в рівнях підготовки студентських груп, які навчались в однакових умовах, однак різняться кількістю студентів в групі, що дозволить звести дані групи як ідентичні при проведенні достовірного порівняння. Аналізуючи статистичні коефіцієнти можна стверджувати, що рівень та якість залишкових знань залишається сталою величиною, не залежно від того, вчили студенти цей матеріал в минулому семестрі, чи в минулому році. Для більш чіткого визначення рівня цих знань потрібно використовувати ширшу оціночну шкалу, а не традиційну п'ятибальну.

Подальші дослідження мають стосуватися визначення статусу залишкових знань та визначенню ознак для перевірки глибини цих знань та можливості порівняння їх в різних контрольних групах. Зміст залишкових знань має бути розроблений спеціальною робочою групою, до якої повинні входити фахівці з даних предметів та потенційні роботодавці. Цей зміст має бути внесений в програми дисциплін.

\section{Список використаних джерел}

1. Кислякова, Ю. Г. Квалиметрическая технология диагностики остаточных знаний студентов : дис. ... канд. пед. наук: 13.00.01. Ижевск, 2002. 158 с.

2. Положення про методику управління та контролю якості навчання у Вінницькому національному технічному університеті /Уклад. В. О. Леонтьєв, Г. Л. Лисенко, Г. П. Котлярова. Вінниця: ВНТУ, 2007. 19 с.

3. Артищева Е.К. Педагогическая диагностика как основа системы коррекции знаний. Образовательные технологии, 2015. №3. C. 85-103.

4. Чмыхова, Е. В., Терехин А. Т. Тестирование знаний студентов и методологические проблемы использования его результатов. Стандарты и мониторинг в образовании, 2010. № 4. С. 25-29. 
5. Крицкая А.Р., Белов Ю.С. К вопросу о формировании остаточных знаний и педагогических измерительных материалов для их контроля в техническом университете. Гуманитарный вестник, 2015, вып. 10 . URL: http://hmbul.ru/catalog/edu/pedagog/303.html

6. Плохинский Н. А. Биометрия. 2-е изд. М.: МГУ, 2015. 368 с.

7. Гублер Е. В. Вычислительные методы анализа и распознавания патологических последствий. Л.: Медицина, 1978. 295 c.

8. Сачанюк-Кавецька Н. В. Кутове перетворення Фішера для аналізу успішності студентів. Матеріали XLVII науковопрактичної конференції. Вінниця: ВНTУ, 2018, URL: https://conferences.vntu.edu.ua/index.php/all-fitki/all-fitki2018/paper/view/4060/3326

9. Урбах В. Ю. Статистический анализ в биологических и медицинских исследованиях. М.: Медицина, 1975. 297 с.

\section{References}

1. Kyslyakova, YU.H. (2002). Kvalymetrycheskaya tekhnolohyya dyahnostyky ostatochnykh znanyy studentov: dys. ... kand. ped. nauk: 13.00.01 [Qualimetric technology for diagnosing residual knowledge of students: dis. ... Cand. ped. Sciences: 13.00.01]. Izhevsk [in Russian].

2. Leont'yev V.O., Lysenko H. L., Kotlyarova H. P. (2007). Polozhennya pro metodyku upravlinnya ta kontrolyu yakosti navchannya u Vinnyts'komu natsional'nomu tekhnichnomu universyteti [Regulations on the methodology of management and quality control of education at Vinnytsia National Technical University]. Vinnytsya: VNTU [in Ukrainian].

3. Artyshcheva E. K. (2015). Pedahohycheskaya dyahnostyka kak osnova systemy korrektsyy znanyy [Pedagogical diagnostics as the basis of the knowledge correction system]. Obrazovatel'nye tekhnolohyy - Educational technologies, 3, 85-103 [in Russian].

4. Chmykhova E. V., Terekhyn A. T. (2010). Testyrovanye znanyy studentov y metodolohycheskye problemy yspol'zovanyya eho rezul'tatov [Testing students' knowledge and methodological problems of using its results]. Standarty y monytorynh $v$ obrazovanyy - Standards and Monitoring in Education, 4, 25-29 [in Russian].

5. Krytskaya A.R., Belov YU.S. (2015). K voprosu o formyrovanyy ostatochnykh znanyy y pedahohycheskykh yzmerytel'nykh materyalov dlya ykh kontrolya $v$ tekhnycheskom unyversytete [On the question of the formation of residual knowledge and pedagogical measuring materials for their control at a technical university]. Humanytarnyy vestnyk - Humanitarian Herald, 10, URL: http://hmbul.ru/catalog/edu/pedagog/303.html [in Russian].

6. Plokhynskyy N. A. (2015). Byometryya [Biometrics]. 2-e yzd. Moskov: MHU [in Russian].

7. Hubler E. V. (1978). Vychyslytel'nye metody analyza y raspoznavanyya patolohycheskykh posledstvyy [Computational methods of analysis and recognition of pathological consequences]. Leningrad: Medytsyna [in Russian].

8. Sachanyuk-Kavets'ka N.V. (2018). Kutove peretvorennya Fishera dlya analizu uspishnosti studentiv [Fisher's angular transformation to analyze student performance]. Materialy XLVII naukovo-praktychnoyi konferentsiyi - Materials of the XLVII Scientific and Practical Conference. Vinnytsia: VNTU. URL: https://conferences. vntu.edu.ua/index.php/all-fitki/all-fitki2018/paper/view/4060/3326 [in Ukrainian].

9. Urbakh V. YU. (1975). Statystycheskyy analyz v byolohycheskykh y medytsynskykh yssledovanyyakh [Statistical analysis in biological and medical research]. Moskov: Medytsyna [in Russian].

\section{APPLICATION OF FISHER'S CRITERION TO ENSURE THE RESULTS OF THE STUDENTS RESIDUAL EVALUATION} N. Sachaniuk-Kavets'ka, V. Kavetskiy

Vinnytsia National Technical University, Ukraine

Abstract.

Formulation of the problem. In modern pedagogical research, a special place is occupied by residual knowledge of academic disciplines, which are fixed in the memory of students at fairly long intervals, but whose role is decisive in their formation as specialists. The problem of reliability of the results of assessment of residual knowledge of students is relevant, because these results are the source information for optimization and modernization of the educational process. In view of the above, it is necessary to find out the possibility of comparing the performance of students of different years who studied in the same conditions on residual knowledge, to choose the criterion of such comparison and to find out whether this knowledge is a constant value.

Materials and methods. To perform the research tasks, the following methods were used: analysis, synthesis, comparison, systematization and generalization of educational-methodical and popular science sources on the research problem, pedagogical experiment, primary statistical processing and generalization of the obtained data. The study was conducted on the basis of Vinnytsia National Technical University at the Department of Higher Mathematics.

Results. In the analysis of residual knowledge on the basis of KKR for the purpose of further adjustment of forms, methods and means of training special methods of their processing are applied, possibility of application of Fisher's criterion (angular Fisher's transformation) for an estimation of presence (absence) of real difference in levels of preparation of student groups under the same conditions.

Conclusions. To ensure a sound decision, it is advisable to apply the Fisher test, which will assess the real difference in the levels of preparation of student groups who studied in the same conditions, but differ in the number of students in the group. Analyzing the statistical coefficients, it can be argued that the level and quality of residual knowledge remains constant, regardless of whether students taught this material last semester or last year. A broader grading scale, rather than the traditional five-point scale, should be used to more clearly define the level of this knowledge.

Key words: assessment of residual knowledge; Fisher's criterion; assessing differences in the preparation of student groups; reliability of comparisons.

\section{$(\mathrm{Cc}) \mathrm{BY}-\mathrm{NC}-\mathrm{SA}$}

This work is licensed under Creative Commons Attribution-NonCommercial-ShareAlike 4.0 International License. 